\title{
The Integrity of Electronic Evidence
}

\author{
Matti Tenhunen \\ Deputy Chief Central Criminal Police, (Interpol-Helsinki), Finland \\ Office: Central Criminal Police, (alias National Bureau of Investi- \\ gation), PO Box 285, 01301 VANTAA, Finland \\ Home: Kyyluodontie 3, 00200 HELSINKI, Finland \\ Telephone, Office (358-9) 838 86507, Home (358-9) 677847 \\ Telefax (358-9) 83886299 \\ Personal E-Mail Address: tenhunen@krp.pp.fi
}

\begin{abstract}
A new branch of Crime Investigation Science, Computer Forensics, or Digital Evidence Analysis has emerged. It supplements the old document investigation (dealing with money, passports, cheques, last wills, business records, etc.) and it is becoming more and more important in a very rapid pace. Computer evidence is not connected to "classical" computer crimes only, it is encountered with crimes of today from murder to child pornography.
\end{abstract}

The Integrity of Electronic Evidence is a prerequisite for its Admissibility in Court Proceedings. As already the Sumerians used Seals, Sealed Envelopes and Trusted Third Party Services to preserve the evidentiary value of their cuneiform clay tablet legal documents, the Information Age has developed applications with One Way Hash Functions and Digital Signatures. The paper discusses the strengths and weaknesses of these methods from the point of view of crime investigations.

It also tries to develop a "Forensic Information Theory", because the modern art of data recording is often unknown or misunderstood by lawyers and many cases are therefore lost in courts. Data and information can not exist without a physical medium or carrier. Computer Evidence is Forensic Evidence and must be treated according to the criminalistic principles developed for collecting and securing it.

"The common need to collect, preserve and present electronic evidence in ways that best ensure and reflect their integrity and irrefutable authenticity, both for the purposes of domestic prosecution and international co-operation, should be recognised. Therefore, procedures and technical methods for handling electronic evi- 
dence should be further developed, and particularly in such a way as to ensure their compatibility between states. Criminal procedural law provisions on evidence relating to traditional documents should similarly apply to data stored in a computer system" (as stated in the Council of Europe Recommendation No. R (95) 13, Appendix, IV. Electronic evidence ).

The Integrity of Electronic Evidence is discussed under the following five chapters: 1. Introduction, 2. Forensic Information Theory, 3. Short History of Document Security, 4. Electronic Evidence Analysis, and 5. Electronic Evidence Manipulation Detection.

\section{Keywords}

Electronic evidence, standards, computer forensics, manipulation detection

\section{INTRODUCTION}

The Council of Europe Recommendation about Electronic Evidence, cited in the end of the Abstract above, matches well with the beginning of our Chairman Leon Strous' Working Conference Annotation:

"Although it is well-known that confidentiality, integrity and availability are highlevel objectives of IT security, much of the attention in the security arena has been devoted to the confidentiality and availability aspects of security. IFIP TC-11 Working Group 11.5 has been charged with exploring the area of the integrity objective within IT security and the relationship between integrity in information systems and the overall internal control systems that are established in organisations to support corporate governance codes."

The Council of Europe, which will celebrate it's 50th anniversary in 1999, has initiated well over 130 European conventions and treaties. Many of them have relevance for Information Security. But the next big COE drafting step will be the most important one: An international convention against computer crime.

To give the reader an overview I will shortly cite here (emphasis added) the Terms of Reference of the Committee of Experts on Crime In Cyberspace (acronym PC$C Y$; it's second session was held in Strasbourg about a month ago):

"The criminal law must therefore keep abreast of these technological developments which offer highly sophisticated opportunities for misusing facilities of the cyberspace and causing damage to legitimate interests. Given the cross-border nature of information networks, a concerted international effort is needed to deal with such misuse. Whilst Recommendation No (89) 9 resulted in the approximation of national concepts regarding certain forms of computer misuse, only a binding international instrument can ensure the necessary efficiency in the fight against these new phenomena.

In the framework of such an instrument, in addition to measures of international cooperation, questions of substantive and procedural law, as well as matters that are closely connected with the use of information technology, should be addressed. 
c. The Committee's terms of reference are as follows: Examine, in the light of Recommendations No R (89) 9 on computer-related crime and No R (95) 13 concerning problems of criminal procedural law connected with information technology, in particular the following subjects;

The Committee should draft a binding legal instrument, as far as possible, on the items i) - v), with particular emphasis on international questions and, if appropriate, accessory recommendations regarding specific issues. The Committee may make suggestions on other issues in the light of technological developments."

The Diplomatic Rogatory Letter Channel, complicated additionally with many Ministries (Foreign, Justice, Interior), is in Investigative International Cooperation Far Too Slow for the Real World Applications.

As Mr. Claude E. Shannon put it in the end of the 1940ies: "A noisy channel contains unwanted signals and requires a filter to take a copy of the transmitted message and compare it to the message received."

Our Chairman asked in his previously cited TC 11.5 Conference Annotation: "Where are the gaps between business needs on the one hand and research and development on the other?"- I would like to answer already here by citing David Kahn, who gives us in his classical book, "The Codebreakers", page 201, the following illuminating example of the gap between R\&D and the real life:

"Wheatstone and Playfair explained the cipher to the Under Secretary of the Foreign Office, no doubt pointing out its chief advantage-that two plaintext pairs that have a letter in common may not display the slightest resemblance in ciphertext, as le and te above were enciphered to MP and NL. Further, once mastered, it rolls along with remarkable ease and rapidity. When the Under Secretary protested that the system was too complicated, Wheatstone volunteered to show that three out of four boys from the nearest elementary school could be taught it in 15 minutes. The Under Secretary put him off.

- "That is very possible," he said, "but you could never teach it to attachés."

What needs to be done to bridge these gaps?, asks Mr. Leon Strous finally. The answer, at least in my mind, is to make both the basics of electronic documents as well as the new mathematical methods of cryptographic one-way hash functions and digital signatures intelligible for the business as well as for the legal community.

I will enumerate the ISO/IEC Hash-Functions (10118-1-4) and Digital Signature Standards (14888-1-3), which can prove "the integrity and irrefutable authenticity, both for the purposes of domestic prosecution and international co-operation" of electronic documents, already here in the Introduction. But beware, they are updated all the time. 
- ISO/IEC DIS 10118-1, "Information technology - Security techniques - Hashfunctions - Part 1: General", International Organization for Standardization, Geneva, Switzerland, 1994.

- ISO/IEC 10118-2, "Information technology - Security techniques - Hashfunctions - Part 2: Hash-functions using an e-bit block cipher algorithm", International Organization for Standardization, Geneva, Switzerland, 1994.

- ISO/IEC DIS 10118-3, "Information technology - Security techniques - Hashfunctions - Part 3: Dedicated hash-functions, International Organization for Standardization, Geneva, Switzerland, 1996 (voting terminates on 1997-04-26).

- ISO/IEC CD 10118-4, Information technology - Security techniques - Hashfunctions - Part 4: Hash-functions using modular arithmetic, International Organization for Standardization, Geneva, Switzerland, 1997 (1997-07-15), voting by October 15, 1997.

- Disposition of Comments Report on ISO/IEC DIS 10118-4, Information technology - Security techniques - Hash-functions - Part 4: Hash-functions using modular arithmetic, Submission 1997-07-15.

- 3rd ISO/IEC CD 14888-1, "Information technology - Security techniques Digital signatures with appendix - Part 1: General", 1997, date 1997-01-02, voting by April 11th, 1997.

- Final text for the 3rd CD ISO/IEC 14888-2, "Information technology, - Security techniques - Digital signatures with appendix - Part 2: Identity-based mechanisms", 1997, consideration 7-11th April, 1997.

- 3rd ISO/IEC 14888-3, "Information technology - Security techniques - Digital signatures with appendix - Part 3: Certificate-based mechanisms", 1997, date 1997-01-02, voting by April 11th, 1997.

I humbly confess, that the concepts of both one-way hash functions and digital signatures are unclear to me and I doubt that that "three out of four boys from the nearest elementary school" could be taught it in 15 minutes.

Later in the "original" 66-page version (will be distributed personally to the participants in Zurich) of this paper, however, I will give the reader some illustrated examples how the information principle of fingerprints or cartridges and bullets can be presented as intelligible evidence to the court. And already here I announce a legally binding public promise to pay 100 USD in cash, if someone in this working conference can do the same with one-way hash functions and digital signatures. I know it can be done. The only thing needed is a real expert to make these complex things simply comprehensible to a person of ordinary understanding. I guess that this audience of experts can pick up such an expert, so chances are I will loose my money.

Intelligibility, as defined in the Black's Law Dictionary, De Luxe Edition, 1992, on page 809 , is the following (emphasis added, as with other citations, too): 
"In pleading, the statement of matters of fact directly (excluding the necessity of inference or argument to arrive at the meaning) and in such appropriate terms, so arranged, as to be comprehensible by a person of common or ordinary understanding. "Each averment of a pleading shall be simple, concise, and direct." Fed.R. Civil P. 8(e)."

This is the same observation what the great Austrian Criminalist, Dr. Hans Gross, stated more than 100 years ago. It was then and still is important to notice that even the best experts were then and still are not criminalists. More likely would everything be lost forever in the criminal proceedings, if the judge cannot understand the basics of what the various experts are saying and all is new and strange to him.

Professor of the University of Graz, Hans Gross, published in 1893 the first edition of his book "Handbuch für Untersuchungsrichter", "Handbook for the Investigating Judge". There he discussed criminalistic topics like Forensic Medicine, Forensic Ballistics, Forensic Photography, etc. based on his own experiences of practical criminal investigations, in a way, which is in essence still valid today. Therefore he has well earned (with Aristotle, see page 7) the name of the Founding Father ("Altmeister und Altvater der Kriminalistik") of Criminalistics.

This old fact is especially $100 \%$ valid in the context of criminal investigations related to modern information technology. The simple answer is, I repeat, to make the complex world of computers and mathematics understandable a for a person of common or ordinary understanding, be this person a Chief Executive Officer, a Commercial Attaché or a Judge or a Member of the Jury in a Court of Law.

Modern Criminalistics (alias Crime Investigation or Forensic Science), as a science and practical work can be defined today as well as 100 years ago to be the sum of such knowledge based systems which create the theoretical and practical basis for crime repression and prevention by legislative actions and other measures.

One application and measure of this art and science is to explain new investigative and evidentiary methods to the "end users" in "simple, concise, and direct manner". There is no difference if we have to give our reasons on the evidentiary value of Fingerprints, DNA, or Electronic Documents Manipulation Detection Code. The basic principle is the same. Present your evidence in such a form, that the judge and jurors can grasp the information principle behind that piece of evidence and also the general concept of evidence evaluation as a whole.

Just the way it was done in the "Old Bailey" (the Central Criminal Court, London) in the "Deptford Murders" case in 1905, described in Jürgen Thorwald's book "Das Jahrhundert der Detektive, Weg und Abenteuer der Kriminalistik" (Zurich 1965, pp. 134-178 in the Finnish version).

Already then the fingerprint expert witness from Scotland Yard used modern presentation techniques with a large wallboard and enlarged photographs to describe the principles of fingerprint evidence evaluation. The defence tried to point the small differences in the prints (which are natural, because every print is unique as such in a strict sense), but Mr. Collins from the Yard took prints of the right thumbs of the ju- 
rors several times and showed these "differences" as natural. Every one in the courtroom could convince himself "beyond reasonable doubt".

In 1911 in the Central Criminal Court, New York, the Judge convinced himself and the jurors by ordering the fingerprint expert to be detained and guarded in his private chamber. Then he ordered 15 persons from the trial audience to step forward and press their right forefingers in certain order on to the window glass. One person was ordered to print his forefinger also on to a glass plate on the desk of the judge.

Then the expert witness, Mr. Faurot, was called back. He solved the problem with his magnifying glass in four minutes. "Very convincing, indeed", said the judge. His name is unfortunately not known. The five (5) "watertight" alibi witnesses of the defense were later sentenced heavily for perjury, too.

This "Grossian" criminalistic approach is very comprehensive in nature including not only the criminal proceedings, the investigation and prosecution in casu, but also the components of legal infrastructures and other protective policing countermeasures in the law enforcement arsenal of the modern society. When the Courts of Law start to understand the way how the integrity of electronic evidence is preserved, then it is more likely that the draftsmen will consider these methods worth of legislative actions. This is, you see, just happening with the DNA legislation in many jurisdictions.

The best book I know how to make DNA evidence intelligible to a layman, is the book by Howard Coleman and Eric Swenson, DNA in the Courtroom, 1995, explaining the complex technology and testimony of DNA in terms anyone can understand. The way information is stored genetically can be compared the way it is stored within a written text. Just as a specific passage in the encyclopaedia can be identified by specifying $a$ volume, page and line number, a specific genetic passage or location, known as a locus, can be identified. A specific naming system identifies genes by numbers issued by the Human Gene Mapping Committee. But let us leave DNA here, however, we will show the deoxyribonucleic acid structure later.

The remainder of this paper is organized as the following Contents in Brief:

- Forensic Information Theory

- Short History of Document Security

- Electronic Evidence Analysis

- Electronic Evidence Manipulation Detection

\section{FORENSIC INFORMATION THEORY}

Information theory, also called the theory of communication, is a branch of Probability theory that has been developed to provide a measure of the flow of information from an information source to a destination. It also supplies a measure of the channel capacity of a communications medium such as a telephone wire and shows the optimal coding procedures for communication. Although originally con- 
cerned with telephone networks, the theory has a wider application to any communication process, even as simple as one human being talking to another. For example in criminal proceedings.

Information theory was developed to a great extent at the Bell Telephone Company laboratories in New Jersey under the auspices of Claude Shannon in the 1940s and '50s. Shannon's original papers first appeared in book form in Claude E. Shannon and Warren Weaver, The Mathematical Theory of Communication (1949, reprinted 1975).

- Claude Shannon deals among other issues with noiseless and noisy channels. In criminal proceedings, if the judge cannot understand the basics of what the various experts are saying and all is new and strange to him, we can also speak of noise in a channel.

But it is probably the fault of the investigator and of the prosecutor, too, if and when they create too much noise and are not able to present the evidence in an understandable manner. The main characteristic of a real expert is, I repeat, the ability to explain complex things so that a judge or a member of the jury has a fair chance to grasp the main idea and basics for example of the evidentiary power and weight behind a (new) criminalistic investigative method like Fingerprint- or DNAIdentification. Or the technical background of electronic documents and how to prove their integrity in a court of law.

- The goal of criminal proceedings is that the facts stated in the verdict are the same as the situation outside the process. This is called as the principle of the material truth.

- The methodology for this fact finding is the empirical truth method. This, of course, does not exclude legal logic; the form of the judgement is a syllogism, just like Aristotle, the greatest of all scientists of all time and the original founding father of criminalistics (see, for example, The Art of Rhetoric, which is the basic handbook for criminal interrogations, Aristotle had also a large collection of court cases, he studied the anatomy of the corpses after battles, etc.) told us more than two millenniums ago.

The evidence is in the scientific literature of most jurisdictions, be they AngloAmerican or Continental, usually divided in two categories:

1. Direct, and

2. Indirect, also called as Circumstantial.

The authoritative Black's Law Dictionary (De Luxe Edition, 1992, p. 556) gives us the following definition:

"There are, generally speaking, two types of evidence from which a jury may properly find the truth as to the facts of a case. One is direct evidence - such as the testimony of an eyewitness. The other is indirect or circumstantial evidence - the proof of a chain of circumstances pointing to the existence or non-existence of certain facts. As a general 
rule, the law makes no distinction between direct and circumstantial evidence, but simply requires that the jury find the facts in accordance with the preponderance of all the evidence in the case, both direct and circumstantial."

But you must verify your source first, even if it is as authoritative as Black's. This "direct evidence", in fact, is not true at all. Expressed for computer people, like this audience, in Boolean logic, it is FALSE. Nothing actually is "direct" evidence. Be it personal evidence, like a witness, or physical evidence, like a document, you have to check first "the bait before swallowing it."

How reliable is this witness? Is this diary written by Adolf Hitler or Benito Mussolini? All evidence must be verified first. In German and English you can put this legal issue straight like this:

- "Jeder Beweis ist Indizienbeweis und nichts anderes."

- " "All Evidence is Nothing But Circumstantial Evidence."

Your witness can have a criminal record of 7,5 kilograms (as, for example, I could inform the Kuopio City Court in one bank robbery false alibi case almost 30 years ago) and the diary you are inspecting as a judge or juror for "discrimen veri et facti" may be written (like, for example, a certain Herr Kujau did in Germany some 13 years ago) on paper with an ink, not available before 1950ies. Not even for a certain Herr Hitler for his diaries ("Tagebücher" from 1934 to 1943). A similar forgery occurred in 1967 with Il Duce's diaries.

In Forensic Information Theory one could classify the types of evidence as: Inceptive, Corroborative, Indicative, Personal, Physical, Shape and Substance, etc. But this is not a forensic dissertation and we will abandon the complicated taxonomy and divide this paper, like Gaius Iulius Caesar did with Gallia (Gallia omnia divisa est in partes tres), in to the following three simple theses only:

- Data is digitally recorded on a medium by leaving it in two distinguishable states.

- All data is material and cannot exist without a physical medium or carrier (it is certainly not immaterial nor quasimaterial).

- Comparison is the method of proving the identity and allowing the conclusion of identification.

Here we can start proving the first two allegations by repeating some of the pages I wrote to Professor (of Criminal and Criminal Procedural Law and Legal Philosophy, Würzburg University, Germany) Ulrich Sieber for his "Comparative Research Study of Dissemination of Illegal Contents in International Computer Networks" five months ago:

- "A GENERAL COMMENT on the TECHNICAL BACKGROUND of ELECTRONIC DOCUMENTS 
The PC-CY held its first meeting at the Council of Europe Headquarters, $14-16$ April 1997. Members of the Committee were invited to explain the situation in their countries concerning computer-related crime and the relevant domestic legislation. Manfred Möhrenschlager mentioned the following (boldfaced here):

"The jurisprudence of courts also tries to adapt to new technologies, e.g. by a wide interpretation (or reinterpretation) of certain notions contained in traditional criminal offences to make them applicable to new electronic forms (for example the notion of "writings")."

Writings or "eine Schrift" is according to (§ $11 \mathrm{Abs.} 3)$ : "Den Schriften stehen Ton und Bildträger, Abbildungen und andere Darstellungen in denjenigen Vorschriften gleich, die auf diesen Absatz verweisen."

You discussed "1. Tatbestandsübergreifende Probleme under a) Schriftenbegriff des StGB" in the second part of "Strafrechtliche Verantwortlichkeit für den Datenverkehr in internationalen Computernetzen."

- This, I think, is the key issue of the whole legal business.

- The basic physics behind all data recording is no more complicated than leaving the medium in two distinguishable states.

- But, unfortunately, amazingly, and with all possible respect, this simple fact seems to be too complicated for the brains of (most) lawyers in the world.

The Honourable Judge is the Key Person. If he does not comprehend, everything is lost. But a good investigator can explain complex things by giving the reasons in well declared chunks of information. The basis for all questions of access control, security features of documents (be they traditional or new ones) as well as fingerprints, DNA, One-Way Hash Functions and Digital Signatures is identification. Already well discussed by Aristotle, the greatest criminalist of all times, in his Metaphysics (Book V., Chapter 9).

The identification is done with characteristics, unique features that when combined, give us evidence beyond reasonable doubt.

The investigative frame is reduced just like the famous Russian probability mathematician A.N. Kolmogorov presented in his "Foundations of the Theory of Probability", in English 1950, the original "Grundbegriffe der Wahrscheinlichkeitsrechnung" was published in 1933.

By combining three characteristics, A, B and C, the picture in the cover of the Finnish edition of Walter R. Fuchs original work "Knaurs Buch der Modernen Mathematik" shows the production rule of probability so very clearly, that even a lawyer (?) can understand it. 


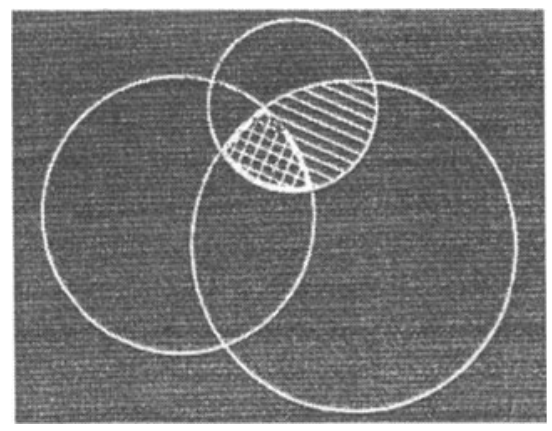

Figure 1. The Production Rule of Probability, Cover page of Mathematics (Matematiikka in Finnish) by Walter R. Fuchs, Munich 1966.

One compares the characteristics (Merkmale) of two different items, which never can be the same. Actually, idem facere, is impossible. The Nature never replicates itself exactly.

To illustrate the very nature of bits and data I will cite John Watkinson, The Art of Data Recording, Oxford 1994, page 9 (here as Figure 2, Basic physics behind all data recording). The whole book is readable even by a lawyer. The graphics alone makes the nucleus of the issue chrystal clear: "The basic physics behind all data recording is no more complicated than leaving the medium in two distinguishable states."

Two magnetic directions
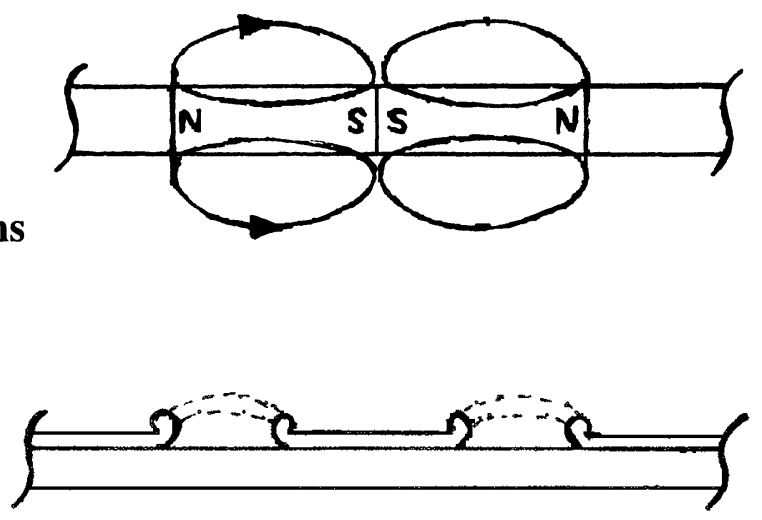

Hole / No Hole

Bump / No Bump

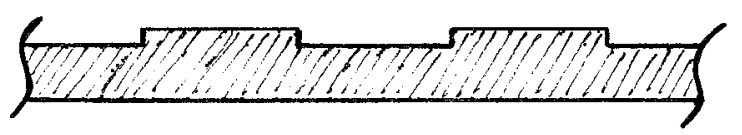




\section{Opaque / Transparent}

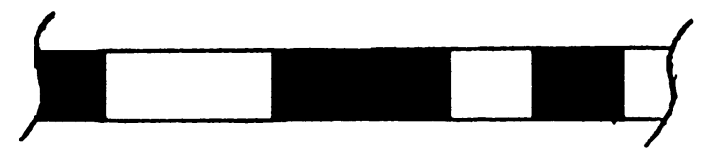

Crystalline / Amorphous
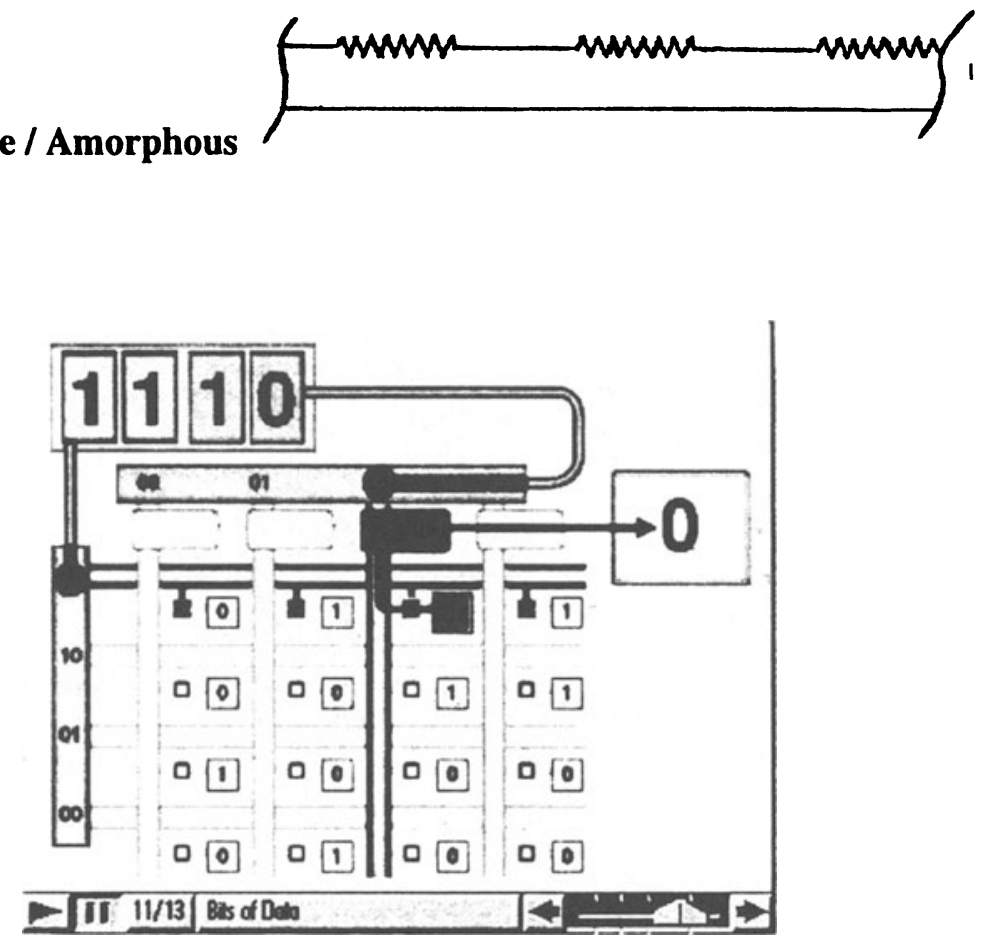

Figure 3. Digital Electronic Writing in ROM, RAM, Warner New Media CD-ROM How Computers Work, The complex world of computers made simple, TIME-LIFE, 1994. Bits of Data to show the electronic writing in RAM and ROM. The latter contains fixed data patterns, the former is volatile (see the short explanation "To store a desired pattern in a ROM is writing", on page 10, too).

The size of the writing is not the point of law, because you cannot draw a line for interpretation, that point 9 is the smallest font allowed, not even for insurance contracts.

For example, Germans were hanged in the US based on evidence of very small documents called microdots, during the WW2. The SVR still takes advantage of professor Zapp's excellent innovation, although compressing documents with film may originally be a French idea from 1871 . 
Microfilm is a legally valid and common way of recording bookkeeping material in most countries.

"IBM" was written with Xenon atoms some five years ago and the competitor Hitachi has developed according to New Scientist, November 1993, a memory cell, which is so small, that it contains only one electron at a time.

One electron or one abacus pearl, there is no legal difference. Both can represent legally relevant data. Which had to be proven.

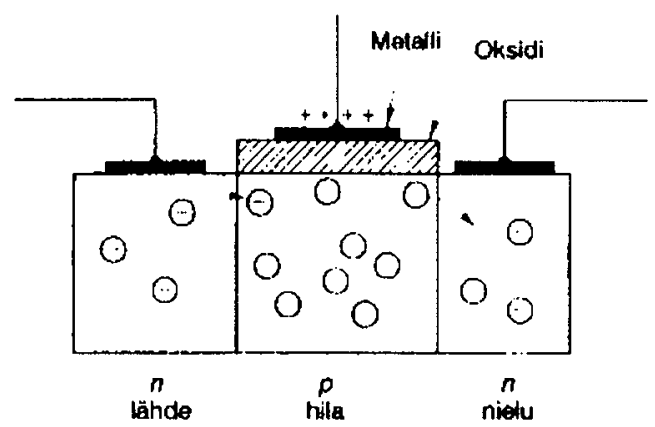

Figure 4. Electron. Metal Oxide Semiconductor Field Effect Transistor (MOSFET), Kvanttipiste, () 1995 Spektrum Akademischer Verlag GmbH, original English version THE QUANTUM DOT, A Journey into the Future of Microelectronics, page 72, Picture 4.4. Switching a positive charge to the director electrode of a MOSFET allows the current to go through the device $(\mathrm{n}=\mathrm{source}, \mathrm{p}=\mathrm{gate}, \mathrm{n}=\mathrm{drain})$.

\section{- To store a desired pattern in a ROM is digital writing.}

For instance, if the ROM is made of enhancement MOS transistors (as in Fig 13.45, not here, but in Microelectronic Circuits by A. Sadra and K. Smith, Toronto 1991, see pages 965-970 with many good pictures), then MOSFETs are included at all bit locations, but only the gates of those transistors where 0 s are to be stored are connected to the word lines; the gates of transistors where 1s are to be stored are not connected. This pattern is determined by the mask, which is produced according to the user's specifications.

Human bodies (as well as those of animals and vegetables) consist of 100 trillions of cells. Each human cell contains a nucleus, within which are 46 chromosomes, divided into 23 pairs, inherited maternally and paternally. The DNA molecule is arranged in these. The genetic code, used for the forensic identification of the dead as well as people alive, consists of four basic building blocks: Adenine, Thymine, Guanine, and Cytosine. It is not as simple as the two state logic, but not much more, because it consists of AT - TA or G - C, C - G pairs, just like red Hearts and Diamonds or black Clubs and Spades:. DNA (acronym for a molecule called 
Deoxyribonucleic Acid) looks in principle like this (in drawing below). It has been described as the basic building block of life, the blueprint of the body. DNA analysis, in the forensic context, is a generic phrase which encompasses various molecular biological techniques that can be used for identification purposes by direct analysis of specific sites on the DNA molecule.

Even in the brain the information is material in the neural network and the nerve cells. My good friend, Dr. of Legal Medicine, Martti Tenhu told me, that the human brain is very IT security conscious and makes several back-ups in various places.

After an empirical study neither a "Machinist" nor a "Soul" is found inside. Throw overboard Plato, Descartes et alii, the whole dualistic concept, outdated for long.

\section{- Simply stated: "Mind Is What Brain Does".}

Final Proof: If you shoot through the Medulla Oblongata (\# 16 in the picture of the "original" version), which was the world famous Modus Operandi of NKVD in Katyn and elsewhere in the Russian jurisdiction) that will be the instant end of all human neural network processing and storing. No more bright and illuminating ideas developed or received. OK?

These and some other principles, which I call "Forensic Information Theory" and try to develop further in my dissertation "Criminal Investigation and IT", are fundamental for both the interpretation of criminal as well as procedural law, and many other legal doctrine areas, because they deal with electronic documents.

- All data is material and cannot exist without a physical medium or carrier.

I am not going here any deeper than citing W. Kässer's Wahrheitserforschung im Straf-prozess, Berlin 1974, page 14:

"Neuere naturwissenschaftliche Forschungen haben gezeigt, dass die Elektrizität durchaus materialer Charakter zukommt, daB also der naturwissenschaftliche Begriff der "Sache" heute auch die Wirklichkeit der Elektrizität deckt.".

This is contrary to our learned friends of the Swedish School (SOU 1992:110 "Datas kvasimateriella karaktär - bara elektroniska laddningar."), but we firmly believe in the Empirical Truth. This, and only this, is the prevalent method in criminal proceedings.

On all empirical things there is only one correct opinion. Kässer cites here Rudolf Carnap, Der Logische Aufbau der Welt, Hamburg 1966, Scheinprobleme § 10: Just like the mountain in Africa, Mt. Kilimanjaro, it's location, height, shape, etc. are empirical things we have to agree upon. 
- Comparison is the method of proving the identity and allowing the conclusion of identification.

The general theoretical background of identification has to be discussed here by necessity in some depth, because it is the basis of applications for the integrity of both electronic and traditional paper documents.

Identification is of Latin origin (idem+facere $=$ to make the same). It means the verification of an item to be that item by comparison of certain criteria, called characteristics. This comparison is the methodical nucleus of all identification (as well as of elimination and reconstruction, for that matter, in criminalistics and in IT security). In plain German:

"Die Vergleichsuntersuchung ist Grundlage für die Feststellung der Identität und deshalb der methodische Kern der Identifizierung."

The ISO (International Organization for Standardization) and the IEC (International Electrotechnical Commission) have given us the following figure to symbolize this "core of the poodle", or "des Pudels Kern", like the original expression of the German poet, novelist, playwright, and natural philosopher Goethe (Johann Wolfgang von, 1749-1832) goes.

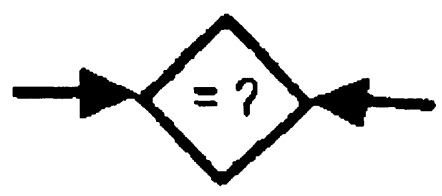

Figure 5. The Compare Icon. 3rd ISO/IEC CD 14888-1, April 11th, 1997, page 6, Legend for the figures: Compare.

The result of the identification process is a conclusion and legally the strength of the evidence supporting the conclusion should be beyond reasonable doubt ("Conviction raisonnée", "kein vernünftiger Zweifel").

The term "identification" is used in computerize sometimes quite carelessly, like the mere password entry would fulfil the criteria, and without including the necessary verification into the concept. Similarly, some people speak loosely about "electronic identity", which actually is just a certification statement of the trusted third party, TTP. The fact that a subject, person, or thing before a court is the same as it is represented, claimed, or charged to be is verified by comparison of characteristics.

In criminal investigations one must take into account that, for example, a fingerprint pattern of our "living" or "dead" customers finger is not at all exactly the same as the image of black ink or computer bit stream in an AFIS-file. One com- 
pares the characteristics (Merkmale) of two different items, which never can be exactly and absolutely the same. OK?

All material objects may be looked upon ultimately as configurations of molecules much as a house is an assembly of bricks. The chance of all the bricks in each of two houses being placed in identically corresponding positions is too remote for consideration. Try to find two identical snow flakes.

Every USD note in your wallet is different. Start by looking not only the number, but the colored filaments, etc. Try to torn the bills in your wallet. Every jigsaw fit of papers can be uniquely authenticated, like the innovators, the old Chinese (and the drug dealers of today) have known for about 1900 years. In forensic Latin it is called Charta Partita, which does not need any English translation.

In 1784, in Lancaster, England, Mr. John Toms was tried and convicted for murdering Mr. Edward Culshaw with a pistol, a broadsheet ballad (a sort of newspaper in verse) and torn off part of it to make a wad for his pistol. He folded the rest and kept it in his pocket. When the dead body of Culshaw was examined, a pistol wad was recovered from the wound in his head. When cleaned and spread out, the wad was discovered to be a piece of a broadsheet ballad. Its torn edge fitted perfectly with the torn broadsheet found in Toms's pocket. This case was one of the first in which genuine scientific evidence was used in court, as my learned friend and perhaps the greatest criminalist of today, Stuart S. Kind, tells us in his book Science Against Crime, 1972 (pages 12-13).

This fact (as Leibnitz told us: $\mathrm{A}=\mathrm{A1}$, and not $\mathrm{A}=\mathrm{A}$ ) is simply true and easily comprehensible, if one considers, for example, his right thumb as an unique original and the prints and marks on various surfaces as replicas and true copies.

- But, as with the simple principle of data recording with two different states, it seems to be too complicated for lawyers here and there to grasp the concept or originals versus copies.

The original electronic document is saved on ones hard drive, and a true copy can be printed with the laser device. This device is again the original one, and one can try to identify the unique characteristics of the toolmarks and the toner it will leave on the paper. Every piece of paper is unique. Every bullet you shoot is unique. The marks left by the barrel will slightly change every time you shoot. This does not, however, prevent us from reading the characteristics and drawing a conclusion.

Now, the "Swedish School" (SOU 1996:40 page 88: "Handlingar kan i IT-miljön knappast sägas utgöra originalexemplar eftersom tekniken bygger på ständigt mångfaldigande av vissa signalmönster - det finns endast ett originalinnehåll."), and some other lawyers, say that there is no more such thing as an ORIGINAL electronic document. It exists only an original pattern of signals, and because the technology is based on standing replication of these signal patterns, one cannot say that documents in IT-environment are capable of being originals. 
Is this argumentation to be taken seriously? NO SIR! Not at all. On the contrary, with all possible respect, it is again legal rubbish just like the "quasimaterial space and place" discussed before (in the "original" version). Because it is fundamental for our topic, the Integrity of Electronic Documents, it deserves some more text here.

I will cite here first the Explanatory Memorandum of the 1992 OECD Guidelines for the Security of Information Systems, boldfacing the issue:

"In common law countries, however, the admissibility of evidence is subject to objection and governed by complex rules. Computer records, like any other documents, may present two issues. The first is authentication: Are the documents accurate and genuine? Are the printouts from the computer admissible either as "originals" or "copies" of the data in the system? In the United States, for example, the federal rules expressly allow authentication and admission of computer records. The second issue that common law systems must address with respect to any document is whether it contains hearsay. This pertains not to the form of the document (whether electronic data or handwritten) but to its content. Generally, it is possible to testify only about matters of which one has direct knowledge and not about something learned from secondary sources. This rule applies to documents as well as to individuals and, while the hearsay rule has many exceptions (the business records rule, for example), this issue must be recognised and anticipated."

Once again: As a thing, strictly speaking, can only be identical with itself, there is only one original. The possibilities of combinations in nature are so vast, that $\mathrm{Na}$ tura non se repetat. Your finger papillaries form the original figure and information of unique characteristics, the minutiae combination. The electronic live scan or the inked paper record is a copy of that. OK?

If a treaty is signed in three versions, one in English, one in French and one in Spanish, there will be three different originals, which are declared to have the same legal effect. But every paper sheet has different fibers, different fingerprints in different places, different signatures etc.

If a signature is $1: 1$, it most probably is an imitation and a fake one, made perhaps by the help of electronic scanning and a pen plotter, because it is impossible to sign your name twice exactly the same way.

A photocopy is not an original. Let me give you just one good forensic example. This is best illustrated by the aforementioned world famous counterfeiting case of the "Hitler Diaries".

By accepting a photocopy as original proof it would have been impossible to see, that the paper used in this scheme was produced several years after WW2, the ink was dated from 1955, the binding materials were not available before 1950ies, and so on. If we believe the forensic identification done in the beginning of the 1970ies (see, for example, Gunnar Johanson, Kompendium i Rättsodontologi, Stockholm 1986 page 14) based on AM and PM dental statuses of Adolf Hitler, and the time of death in 1945, the case is clear: a clever criminal attempt of Mr. Kujau to get money. 
By accepting mere photocopies as evidence, it will impossible in other cases, too, to analyse the original paper, writing and other information with the help of a professional document examiner.

The situation is no different with a) electronically, b) magnetically and c) optically produced documents. Let me describe here three forensic computer evidence cases from my well over 500 domestic and international Computer Crime and Evidence Case Database:

- The VPC Magnetic Tape Manipulation Case, 1986, Sweden,

- The World Trade Center Terrorist Bombing Case, 1993, USA,

- The Insulin Murder and Fake Suicide Letter Case, 1995, Finland

1. The VPC Magnetic Tape Manipulation Case, 1986, Sweden, is a classical example.

This case made also history for Forensic Toolmark Analysis. The 9-Channel Magnetic Tape and the Read and Write Head were analyzed with the best forensic skill (and a lot of money) available in Sweden, Germany and USA. With precision tools one could show, that the magnets in the head presented a unique pattern suitable for criminalistic identification beyond reasonable doubt. The unique head makes unique magnetic patterns on the tape.

Similarly, the German BSI (Federal IT Security Agency, Bundesamt für Sicherheit in der Informationstechnik) has developed a Toolmark Analysis system to recognize, if a diskette (with a computer virus) was copied on a certain professional drive or produced with an ordinary off the shelf PC.

2. The World Trade Center Terrorist Bombing Case, 1993, USA, is an example par excellence for deeper legal understanding of what constitutes an ORIGINAL.

This famous case is well described in the Revue Internationale de Police Criminelle, Numero 452-453, 1995, on pages 32-36, Dave Williams, "L'attentat contre le World Trade Center de New York."

The bombing took place on February 26, 1993. A rented Ford F 350 Econoline loaded with nearly 800 kilos of explosives and detonators was left to the WTC underground parking area. The explosion displaced 6800 tons of materials, killed 6 persons, wounded 1000 and 50.000 people were evacuated.

From the huge amount of the debris around the 50 meter explosion crater the crime scene investigators were able to find the decisive fragment of the chassis of the vehicle. This piece of evidence revealed in the laboratory the serial number of the rented Ford. This lead to the company, from which one of the terrorists had rented the car. One individual by the name of Mohammed Salamed had telephoned to the car rental company and reclaimed for compensation for his damages caused by the bombing incident. This lead to the arrest and searches of premises. In the context of these searches the investigators seized one microcomputer, which revealed the most important evidence. The FBI Computer Analysis \& Response Team, CART, Field Examiner Program was awarded in September 1994. 
But before that, on March 3, 1993, the New York Times had received a letter concerning the bombing of the World Trade Center. This letter was sent in the name of ALLAH. In fact, this was not the original thing and as we all, lawyers included, may have guessed, ALLAH had no part in this scheme. The ORIGINAL letter was on the harddrive of Mr. Nidel Ayyad, a chemist from New Jersey.

Three Muslim Extremists were convicted in 1994 and three more in 1996. These individuals were also planning to explode the United Nations Headquarters in New York.

3. The Insulin Murder and Fake Suicide Letter Case, 1995, Finland. Insulin is normally used as a medicine, but it can also kill.

Suicide letters are commonly used as explanations why someone wanted to leave his/her goodbyes to this wicked world. In this case the local police found a paper letter starting with: "DARLING, I love you most of all, but ....", in the suitcase side pocket of the deceased. Sometimes these letters are fake, but very rarely the ORIGINAL (digital) suicide letter is found on the workplace computer of the merry widow, 50 miles away from home.

The hard-drive of her workplace (a hospital in another commune) computer was analyzed by the Central Criminal Police Computer Crime and Information Security Unit. There were three different versions of "DARLING, I love you most of all, but ....".

The widow in spe had become more and more greedy, adding twice certain valuable property items as his last will.

The Turku Court of Appeal gave the Verdict in May 1996: Murder, Sentence: Lifetime imprisonment. The original letter was the decisive evidence. Despite of this she never confessed.

- Identitas vera colligitur ex multitudine signorum - True identity is collected from a multitude of signs.

- Information is variety. Information and evidence are two closely related aspects of the same phenomenon. In the absence of variety there is no information and no evidence. Evidence can be looked as an investigative or a verification tool.

The ISO/IEC documentation is excellent, but targeted to experts, and never understood by ordinary mortals in a Court of Law. Please, ask your ISO/IEC representative and verify by yourself. If you understand, which is very possible, is only half a battle won. But can you teach it "to attachés?"

No. It needs the addition of the layman understandable basic idea, like the analogy in explaining the DNA Identification with a specific passage in the encyclopaedia, identification by specifying a volume, page, and line number, a specific genetic passage or location, known as locus, can be identified. 


\section{SHORT HISTORY OF DOCUMENT SECURITY}

In criminal law much effort has been wasted for the definition of the object of forgeries, writings and documents. The situation is similar to a man, who has lost his memory. The only way to understand the current and comprehend something about the future, is to look backwards and try to see the symmetry by the inductive method. Comparison with the past will reveal, that there is nothing new under the sun, nil novum sub sole.

The Finnish answer to the OECD Questionnaire "Review of the 1992 Guidelines for the Security of Information Systems" included a year ago the following nutshell description "how the Art of Secure Writing has evolved":

"The revised version of our Guidelines could perhaps include a short History of Document Security, beginning with the innovation of writing systems (and forgeries, as good and bad are only the different sides of the same coin from the security point of view, for the effective protection strategy one must master both).

In Babylon and Assyria the clay tablets and cuneiform writing reached a high security standard by using seals, sealed clay envelopes for contracts like bills of lading, notary public systems and trusted third parties and witnesses.

The Helsinki University Neo-Assyrian Document Project, lead by the world famous professor Simo Parpola, contains about 30.000 clay tablets from Ninive, where the arson of the library made these documents very durable for long time archiving. Many of these are legal documents, allowing the study of the security features and legal forms. They are now all in a database, in original graphical form, transliterated into Assyrian as well as into English language.

Actually the Finnish (and Danish, Swedish, Norwegian and Icelandic, as these laws have been produced in a joint Nordic Legislative Project) Sea Act, 1994, Chapter 13 Transport of Goods, Section 46, Contents of Bill of Lading, which allows the signatures to be produced either mechanically or electronically, is less secure a document than the Assyrian equivalent 3000 years ago.

The Assyrian Bill of Lading, written in cuneiform on a clay tablet, sealed in a clay envelope bearing the same text on the cover, showed extraordinary intellectual power to secure information for shipping goods in the golden crescent area of the Euphrates and Tigris waterways. It had a strong Maritime Fraud preventive effect and it reduced efficiently the amount of possible court disputes. The case is almost the opposite nowadays, because the international security standards of Bills of Lading are inferior.

The Notary Public System, Tabularius, was a powerful evidentiary scheme of the Romans, too. The Chinese used and still use today the "Charta Partita", 
and very interestingly, fingerprints as foolproof signatures. The earliest paper documents with "digital" (a digit means originally finger) signatures, now about 1200 years old, have been found in Khotan (Chinese: Hotan), a city in the western part of China's Xinjiang (Sinkiang) Autonomous Region, near the Indian border.

According to Robert Heindl, Daktyloskopie, Berlin u. Leipzig, 1927, Mr. TsaiLii is credited for innovating paper about 152 A.D. See this excellent book for the full texts of the two legal documents signed by the contracting parties and two witnesses with their fingerprints:

"Die beiden genannten Urkunden enthalten - und das ist für uns das Wesentliche - zum Schluss die Formel: "Die zwei Kontrahenten fanden es recht und billig und haben den Abdruck ihrer Finger als Signatur beigefügt."

In Finland, an ingenious system combining two pieces of Wooden Charta Partita, was used in the middle ages and even later until the 20th century (in the "original" and much longer IFIP-version Figure 9, p. 16). You can see the unique and perfect fit of the annual rings and fiber patterns. This is impossible to imitate and copy. Perfect for evidentiary use.

But the whole history should not be told in full here in this preliminary letter, but just give the reader some examples how the Art of Secure Writing has evolved. The old solutions seem to be much better than the new ones, at least in some respects.

"Scripta Manet" said the old Romans. Today the average standard of electronic, optical and magnetic writing is the opposite: Scripta Digitalia Non Manet - Digitally Written Disappears.

The innovation of Tsai-Liin, as perfected after two millenniums in the contemporary Finnish paper with the longest, thinnest and most robust fibers in the world, is without any doubt to be most reliable information platform for the third millennium, too.

- By studying the past we can better understand the present, and perhaps have a vision for the future.

Now, there is much preparative work on electronic signatures done. Some countries, like Sweden (Elektronisk dokumenthantering, Betänkande av ITutredningen, SOU 1996:40, with English Summary on pages 15-23) and Germany (Gesetz zur digitalen Signatur, Signaturgesetz, SigG, Referentenentwurf, Stand 19. September 1996) have even come out with proposals for Bills.

But both of these bold efforts lack of a deeper analysis of the real world applications. In other words they have not a de lege lata inventory and 
analysis of the various sections of acts and decrees regulating the signatures, seals and other document security features of the present and legally valid paper documents.

I have collected from the Finnish Legal Database, FINNLEX, about 800 sections of various Acts and Decrees, which regulate the legal requirements for different kinds of documents, ranging from various kinds of contracts to tax declarations and court decisions. The analysis of this material is the next step to be done in the near future.

Because there has not been an effort to collect this vital information, neither the Swedes nor the Germans have not been able to analyse the current situation at all. This has been left for the future work. Unfortunately.

The German paper mentioned above states on page 3, Ziel des Gesetzes, The Aim of the Act:

"Soweit durch Rechtsvorschrift die Schriftform vorgegeben ist, wird sukzessive geprüft, ob und in welchen Fällen es zweckmässig erscheint, neben der Schriftform auch die "digitale Form" mit digitaler Signatur zulassen."

The "Successive Test Method" looks only by prima facie good. Instead of this mere solution postponement trick, analogue to head hiding familiar to some Australian birdwatchers and European harehunters, we could use the old, tested and as good proven OECD recipe, to study the problems:

"at an early stage on issues related to information, computer and communications technologies and policies and their effects on society, with a view to raising awareness on an international level and assisting governments and the private sector as they undertake national deliberations."

Because this effort needs worldwide harmonization and standards, I think Objective 5. "collecting information concerning future work on security of information systems in the OECD" could be interpreted to encompass the collection of the basic ideas in the PKI and Digital Signature drafts of various member countries. We could start with the Canadian Legal Study of PublicKey Infrastructure, February 1995.

The European Union is having various projects (like Telecommunications and Value Added Services, S2101 Requirements for Trusted Third Party Services), but they are not comparable to what the best OECD Legal Experts can draft.

Not all lawyers are equal in analysing the way how the evidentiary value of electronic documents should be guaranteed de lege ferenda, and besides, most of the Brussels' project people are, with due respect, just "humble engineers and mathematicians". 


\section{ELECTRONIC EVIDENCE ANALYSIS}

The history of Documentary Evidence Analysis is, as we have seen in the previous chapter, as old as the documents themselves. It had before, as well as today, mainly a procedural and evidentiary law nature. The famous 1734 Years Law, of which some minor parts are still valid in Finland (but not in Sweden any more), was a product of condensed legal wisdom of many centuries. The Procedural "Balk", Chapter 17, Section 1, stated extremely well and clearly the nucleus of our topic as follows:

"If someone presents documentary evidence, to strengthen his case with them, the judge shall investigate thoroughly their art and original nature and what power of evidence and effect they may have in the judgement of the case."

The main legal issue, of course, is still, that in order to be legally relevant, both the traditional and the new electronic documents shall fulfil the basic demand, a procedural precondition, that the authentication of their originator and their contents must be possible for the judge himself. In this preliminary problem, called Admissibility in Anglo-American Law, the judge and the jurors, may get help, for example from the document examination experts of the Metropolitan Police, FBI or Central Criminal Police Crime Labs.

The material evidentiary power of a document presupposes a formal evidentiary power. This is the case, if the document is genuine or originated by a person who is declared the issuer (this is expressed in legal Latin with the word Veritas), and, if the document is not forged or such that it is not altered afterwards (this is expressed in legal Latin with the word Bonitas). ${ }^{1}$

Without evidentiary power, formal and material, the documents do not enjoy publica fides. The mere unstability of the publica fides for the currency of one country or, say, the mobile phone system can cause serious problems for the national economy for one or many country.

Writing systems began with ownership markings. The reindeer ear (see "original" page 14 for details) is quite correctly ruled to be a document by the Finnish Supreme Court Decision in 1962. The new ownership markings of the digital mobile phones, called International Mobile Equipment Identity (IMEI) and Subscribers Identity Module (SIM) are the same thing: documents. Manipulating them is forgery.

1 See Tauno Tirkkonen, Finnish Criminal Procedural Law, Documentary Evidence, Suomen rikosprosessi-oikeus II , Porvoo 1962, II $50 \S$. Kirjalliset todisteet. The wise text referred here is on page 239. Unfortunately, due the language barrier, you cannot understand a word. Finnish is ranked by the US Embassy Standards as Hardship \# 5 Category, just before Chinese. 
A new branch of Crime Investigation Science, Computer Forensics, or Digital Evidence Analysis has emerged. It supplements the old document investigation (dealing with money, passports, cheques, last wills, business records, etc.) and it is becoming more and more important in a very rapid pace. Computer evidence is not connected to "classical" computer crimes only, it is encountered with crimes of today from murder to child pornography.

We already had examples of Electronic Evidence Analysis in cases like the VPC Magnetic Tape Manipulation Case, 1986, Sweden, the World Trade Center Terrorist Bombing Case, 1993, USA, and the Insulin Murder and Fake Suicide Letter Case, 1995, Finland. But to put the reader rapidly in medias res I will cite here (=in the "original") next a highly respected source, the Royal Canadian Mounted Police Information Technology Security Bulletin. As you might not know, this world famous police force was tasked already in 1973 by the Canadian Government for IT-Security for the whole Canada, the largest country of the world of today.

- Their Web-Site is always worth of visiting. You will also be able to download the whole Computer Forensics: An Approach to Evidence in Cyberspace, by Special Agent Mark M. Pollitt, Federal Bureau of Investigation, Baltimore, Maryland• , RCMP IT Security Bulletin, April 1996 pp. 5-7.

In the context of the 1992 EICAR (European Institute for Anti-Virus Research) Conference I learned, that the worlds first unit to evaluate computerized criminal evidence was opened in the Bavarian Landeskriminalamt by Unit Chief Werner Paul, already back in 1976. Paul gave us in the Siemens-Nixdof premises an excellent discussion about computer crime and electronic evidence in 1992. Later, when I had the honor to visit and admire his Unit in the LKA München located in the City area, Chief Paul, a real pioneer in his field, stressed to me the basic principle and bottom line of the whole business:

- "Computer Evidence is Forensic Evidence and Must Be Treated as Such."

Symposia on Forensic Science have been held by the I.C.P.O.-Interpol at regular intervals since 1963. At each of these, the participants draw up a list of Research Projects to be completed for presentation and discussion at their next meeting. Other symposia have been held to deal more specifically with the identification of persons and the handling of traces and evidence.

The FBI Academy, Quantico, Virginia, arranged on 21-25 June 1993 an International Law Enforcement Conference On Computer Evidence. This was a milestone, too, in the history of Questioned Data Media Investigation. The conference was attended by about 60 people, with an equal representation from U.S. Federal Agencies, U.S. State and Local Agencies, and International Law Enforcement Agencies.The purpose of the conference was to explore the various methods used by agencies in analyzing the content of computer-related evidence media (disks, tapes, etc.) with the intent of developing a set of criteria that could be used in es- 
tablishing standards for such forensic analysis. To this end the group created four separate committees:

The Second International Conference on Computer Evidence was arranged in Baltimore, Maryland, USA, April 10-14, 1995. The following Interpol Member States were represented: Australia, Brazil, Chile, China (Republic of Taiwan), Israel, Finland, France, Germany, the Netherlands, the United States of America and United Kingdom.

The bylaws of the International Organisation on Computer Evidence (IOCE), were published April 3, 1995. The objectives were set by the IOCE Executive Board for the third conference held in Melbourne, Australia from 14-16 February 1996.

The Fourth was arranged in the Hague by the Netherlands November 10-12, 1997, dealing with technical, legal and procedural issues of computer evidence. Participants, among them people not only from the Computer Crime Units of twelve countries, but from Interpol HQ, Council of Europe, The European Commission, Amsterdam and Würzburg Universities, Ministries of Justice of Finland, the Netherlands, etc., visited the forensic science laboratory where a number of state of the art forensic methods for analysing computer evidence were demonstrated.

\section{ELECTRONIC EVIDENCE MANIPULATION DETECTION}

Electronic Evidence Manipulation Detection is important not only for the Law Enforcement and Forensic Community, it is essential for the whole Law of Evidence in any jurisdiction (areas of authority; the geographic area in which a court has power or a legal system applies).

We have in Finland, as in many other OECD member countries, currently several projects to create the basis for the wider use of Electronic Documents, i.e. the Public Key Infrastructure with Certification Authority, Smart Cards and Digital Signatures.

Contracts and other documents cover a vast area in legal life. But this is not a question of contract and obligation law only, as for example, the Finnish preparatory work of the future legislation presupposes.

On the contrary, both administrative and procedural law are most important. For example: your tax declaration is no contract at all. ${ }^{2}$ Neither are the various

\footnotetext{
${ }^{2}$ Professor Veli Merikoski used to tell ex chatedra the following story: One Finnish seaman mailed back his declaration with the text: "Despite of your brochure I have no intention to join your association as a member." He did not succeed, because there is no contract be-
} 
decisions of tax officials nor their dossiers. The same applies to the documents and decisions of the courts, lower and higher, they must be signed and sealed to be legal and to enjoy evidentiary value. The principle of free evaluation of evidence does not change the situation.

A signature is according to the current legislations (be they Finnish, Swedish, German, or, I guess, any other) a biometric security feature (Identity Verification by Personal Characteristics), and it cannot as a rule without scpecially tailored legislation be replaced with digital signatures, which are security features based on what someone knows (Identity Verification by Something Known). "Sesam Open" could identify neither Ali Baba nor the 40 bandits.

I attended in Brussels a SOGIS (Senior Officers Group Information Security) meeting in December, 1993, and learned there the existence of Dr. Ulrich Seidel's work of nearly 200 pages, named "Bestandsaufnahme über die elektronischen Signaturvarfahren". One citation alone from it will verify what was said before about the need for legislative actions:

- "Das Eigenhändigkeitsprinzip der Unterschrift ist im geltenden Recht als biometrisches Prinzip ausgestaltet, kann also nicht durch logische Sicherungstechniken substituiert werden".

A different thing is, that since the American painter Samuel F. B. Morse built in 1843 the first telegraph line between Baltimore and Washington, and equipped his device with an apparatus that recorded the message on a paper tape as "dots" and "dashes", the businessmen have been able to make EDI-contracts among themselves. Important messages were sent back from the receiving station and verified against an extra $50 \%$ payment.

The wireless, telex or telefax did not change the situation at all in principle. Contracts are made easily with fax exhange. Fax is also popular in investment fraud schemes. The principle of free formation of contracts is well illustrated, for example, in London and other Stock Exchanges, where standardized hand signs are used in dealings with options and futures. The evidence is recorded on videotape.

Home Banking, too, makes use of the free formation of contracts. The bank and the customer sign a paper, where they declare a PIN, a session key and a transaction verification key to be equal to a signature on a written contract. Electronic money transfers between banks are also based on agreements.

However, our main target for manipulation detection and prevention in this conference, organized by the IFIP TC 11.5, devoted to integrity and internal control in information systems, in cooperation with the International Federation of Accountants (IFAC), IT-Committee, the Swiss Informaticians Society (SIS), Sub-Group

tween the taxpayer and the government. Tax officials since the Sumerians interpret the obligation quite correctly as mandatory. 
Information Security, the Dutch Computer Society (NGI), Special Interest Group on Information Security and hosted by the SIS / University of Zurich, Department of Computer Science, is twofold:

1. Bookkeeping, the art and science of recording business accounts and transactions, and

2. Seizure of Electronic Evidence, which covers the universe of documentary materials not limited to business records.

- The International Federation of Accountants (IFAC), IT-Committee especially could consider the possible future use of one way hash functions in bookkeeping.

I made a similar effort with the Nordic State Auditing Offices Conference in September 1997 in the beautiful city of Copenhagen by distributing them the text I presented also for the EICAR Conferences in Linz, December 1996, and in Hamburg, September 6-9, 1997.

Before ending this paper with the text mentioned in the previous paragraph I will generally comment both of these important areas, bookkeeping and seizure.

The Finnish Bookkeeping Act, 1973, for example, stipulates in Section 8 as follows:

"(1) The bookkeeping shall be based on a dated and numbered receipt, which verifies the business transaction.

(2) The receipt can be, according to the decision of the Ministry of Trade and Industry, recorded as a microfiche or on film or on other media readable with a magnifying device, and, if needed, made visible as a traditional paper document."

If the diaries of Adolf Hitler and Benito Mussolini had been "verified" by microfilms, it is very likely, that Mr. Kujau and not the original chiefs / thieves would write the history.

- There obviously is a so called "social call" for one-way hash functions. Without them there is no more Audit Trails (Chain of evidence connecting account balances or other summary results to original transactions and calculations, says my Black's Law Dictionary, p. 131). How it is realized in contemporary applications, is the next good question.

- In bookkeeping we are shifting now to digital images of receipts on CDROM.

But now it is time to copy the text presented to EICAR and the Nordic Government Auditors some months ago. 


\section{- 'IT-Evidence Authentication: a) Digital Signatures or b) One Way Hash Functions?}

Because I presume this audience, if any, is computer literate, I would like to finish my paper by presenting to you one important question:

Which approach should be considered better for Evidentiary Purposes, a) Digital Signatures or b) One Way Hash Functions?

Bruce Schneier explains the drawing How Digital Signature Works, Hands On Under the Hood, BYTE, November 1993, page 310 (see the images on pages 55-56 of my IFIP-"original"), as follows:

"Suppose an electronic document or message (m) is to serve as a legal instrument. The signer uses the SHA to create a hash value of the document's contents, $H(m)$. Next the signer selects public prime numbers $p, q$ and $g$, a random number $k$ and $a$ private key $x$. These values and the hash are supplied to the DSA, which creates the signature values $s$ and $r$. The verifier provides the DSA with the document's hash value; the signature $s$; the same $p, q$ and $g$; and the public key $y$. If the result ( $v$ ) from the verifier's DSA matches the other signature value $r$, then the signature is valid. This also proves that the documents contents have not been altered."

A drawing about "Simplified Classification of Cryptographic Hash Functions and Applications" is found in Handbook of Applied Cryptography by Menezes at alii, 1997, on page 324. The authors have dedicated pages 321-383 to Hash Functions and Data Integrity (Chapter 9). The introduction allows us to see the essentials very clearly:

"The basic idea of cryptographic hash functions is that a hash-value serves as a compact representative image (sometimes called an imprint, digital fingerprint, or message digest) of an input string, and can be used as if it were uniquely identifiable with that string.

Hash functions are used for data integrity in conjunction with digital signature schemes, where for several reasons a message is typically hashed first, and then the hash-value, as a representative of the message, is signed in place of the original message (see Chapter 11). A distinct class of hash functions, called message authentication codes (MACs), allows message authentication by symmetric techniques. MAC algorithms may be viewed as hash functions which take two functionally distinct inputs, a message and a secret key, and produce a fixed-size (say e-bit) output, with the design intent that it be infeasible in provide data integrity and symmetric data origin authentication, as well as identification in symmetric-key schemes (see Chapter 10).

A typical usage of (unkeyed) hash functions for data integrity is as follows. The hashvalue corresponding to a particular message $\mathrm{x}$ is computed at time $\mathrm{T} 1$. The integrity of this hash-value (but not the message itself) is protected in some manner. At a subsequent time $\mathrm{T} 2$, the following test is carried out to determine whether the message has been altered, i.e., whether a message $x$ ' is the same as the original message. The hashvalue of $x^{\prime}$ is computed and compared to the protected hash-value; if they are equal, 
one accepts that the inputs are also equal, and thus that the message has not been altered. The problem of preserving the integrity of a potentially large message is thus reduced to that of a small fixed-size hashvalue. Since the existence of collisions is guaranteed in many-to-one mappings, the unique association between inputs and hashvalues can, at best, be in the computational sense. A hash-value should be uniquely identifiable with a single input in practice, and collisions should be computationally difficult to find (essentially never occurring in practice)."

Digital Signature, to make clear the terms before discussion like Aristotle (384322 B.C.) used to do, could be defined as in Davies-Price, Security for Computer Networks, 1984:

"A number depending on all the bits of a message and also on a secret key. Its correctness can be verified by using a public key (unlike an authenticator which needs a secret key for its verification)."

"A key-dependent one-way hash function is often called a MAC, for Message Authentication Code. MACs have the same properties as the one-way hash functions, but they also include a key. Only someone with the identical key can verify the hash."

Kriminalhauptkommissar Joerg Rosemann, a prominent investigator of the LKA North Rhine Westphalia, describes in his article "Die elektronische Unterschrift, Einsatz digitaler Signaturverfahren im Rahmen der EDV-Beweismittelsicherung" how to secure the integrity of electronic evidence with Digital Signatures. ${ }^{3}$

Trial Attorney Martha Stansell-Gamm ${ }^{4}$ wrote in the aforementioned "Federal Guidelines: Searching and Seizing Computers", about Authenticating Electronic Documents, Solutions: Digital Signatures.

"One of the potential solutions to this problem may also be electronic: "digital signatures." The Digital Signature Standard would allow authors to encrypt their documents with a key known only to them. Assuming the author has not disclosed his password to others, this identifying key could serve as a sort of electronic evidence seal. In that event, the signature would be just the kind of "distinctive characteristic" the rules already recognise."

OK-But. There is, I think, even a better solution than encryption for the evidentiary verification procedure: One Way Hash Functions which produce a Message Digest. Message Digests are designed to reliably detect any modification of the data of which the digest is computed.

\footnotetext{
${ }^{3}$ See Kriminalistik 8-9/94, pp. 575-578.

${ }^{4}$ Computer Crime Unit, General Litigation and Legal Advice Section, U.S. Department of Justice, Criminal Division.

${ }^{5}$ See the whole well written Part VIII EVIDENCE, pp. 113-123, A. Introduction, Federal Rules of Evidence, B. The Best Evidence Rule, C. Authenticating Electronic Documents, 1. "Distinctive" Evidence, 2. Chain of Custody, 3. Electronic Processing of Evidence, D. The Hearsay Rule.
} 
Bruce Schneier gives in his well crafted and extremely readable book "Applied Cryptography: Protocols, Algorithms, and Source Code in C" the following Background:

"A one-way hash function, $H(M)$, operates on an arbitrary-length message, $M$. It returns a fixed-length hash value, $h . h=H(M)$, when $h$ is of length $m$.

There are many functions that take an arbitrary-length input and return an output of fixed length, but one-way hash functions have additional characteristics:

Given $M$, it is easy to compute $h$.

Given $\mathrm{h}$, it is hard to compute $\mathrm{M}$.

Given $M$. it is hard to find another message, $M^{\prime}$, such that $H(M)=H\left(M^{\prime}\right)$.

"Hard" depends on the specific security requirements of the situation, but most realworld implementations define hard as requiring on the order of $2^{64}$ operations, sometimes even more.

There are two basic attacks against a one-way hash function. The first is the most obvious: given the hash of message, $\mathrm{H}(\mathrm{M})$, adversaries would like to be able to create another document, $M^{\prime}$, such that $H(M)=H\left(M^{\prime}\right)$. If they could do this, it would undermine the security of every protocol that uses the one-way hash function. The point of the one-way hash function was to provide a "fingerprint" of $M$ that is unique. If Alice signed $M$ by using a digital signature algorithm on $\mathrm{H}(\mathrm{M})$, and Bob could produce $M^{\prime}$ such that $H(M)=H\left(M^{\prime}\right)$, then Bob could claim that Alice signed $M^{\prime}$."

In MacOS Power-Talk used the Message Digest 5 (MD5) algorithm to summarize a digital document into a unique 128-bit number.

Think of MD5 as one big math equation that takes all the bytes in a digital document and pops out one 128-bit number. Alter one bit in the document and it summarizes to a different 128-bit number. A similar possibility has existed for a long time in the UNIX-environment. This 128-bit number can be reduced in hexadecimal (HEX) notation as 32, which is less than half the size of this line (something like B1 4E 2A BD 9608 8B A4 6783 D1 09 FE 5256 6C).

This number, which can be calculated for one file or many files, whatever suits best for the investigation in progress, is given to a witness, who, if needed, can testify in court in cases of dispute. Or it can be registered with a time stamp into a reliable sequential database. It can also be written down in the official protocol of the search and seizure. A copy of it can be given to the suspect or his lawyer. It can be added to the CD-Rom image dump copy taken with the Disk Image BackUp System.

Signing the message digest rather than the message often improves the efficiency of the Digital Signature process, because the message digest is usually much smaller than the message.

But in the verification process of criminal investigations, as recommended by the Council of Europe, alone, in Authenticating Electronic Documents, be they seized hard drives or records of electronic bookkeeping, we do not necessarily need encryption. 
- Encryption easily causes problems if there is any kind of malfunction. Encryption can be dangerous for evidentiary goals.

- Neither do we absolutely need public or secret keys for IT-evidence authentication. And these niceties are only available for investigators, if there is a Public Key Infrastructure (PKI) in their country.

This is not reality in many jurisdictions yet, perhaps only in the USA. Kriminalhauptkommissar Rosemann mentions for Germany the TeleTrust Deutschland, with BSI as a partner, but does not indicate if and when the system is/will be operational. The Postal Services of the Nordic Countries have a system with Chipcards, "Nordic Post Security Service", operational from Summer 1997.

According to Bruce Schneier's above mentioned book: ${ }^{6}$

"A smart card is a plastic card, the size and shape of a credit card, with an embedded computer chip. A smart card contains a small computer (usually an 8-bit microprocessor), RAM (about a quarter kilobyte), ROM (about 6 or 8 kilobytes), and either EPROM or EEPROM (a few kilobytes). Future-generation smart cards will undoubtedly have more capacity, but some physical limitations on smart cards make expansion difficult. The card has its own operating system, programs, and data. (What it doesn't have is power; that comes when the card is plugged in to a reader.)"

Today MD5- Message Digest is made Shareware by the RSA. The National Institute of Standards and Technology, along with the National Security Agency, has designed the Secure Hash Algorithm (SHA) for use with the DSA. The standard is the Secure Hash Standard (SHS); SHA is the algorithm used in the standard. ${ }^{7}$

One-Way Hash Functions have probably many other applications in Crime Prevention and Detection. If a hacker has changed passwords or put sabotage software into the system, these tricks can be checked by One-Way Hash Functions. ${ }^{8}$

Think then about Business Records, the Bookkeeping. If companies had to use timestamped message digests for their records and these digests had to be registered for example in the Ministry of Industry and Trade from time to time, it would obviously be slightly more difficult than today to produce:

- one set (\#1) of the bookkeeping for the tax officials,

- another (\#2) for the bank,

- and a third (\#3, the real) one for the managers.

\footnotetext{
${ }^{6}$ See 24.13 SMART CARDS, from page 587.

${ }^{7}$ Bruce Schneier has described One Way Hash Functions more closely in his "Applied Cryptography: Protocols, Algorithms, and Source Code in C." In the end of Chapter 14 he answers the question "Which One-Way Hash Function Is Best?": "I vote for SHA; it's longer than the others and was developed by an organization that knows what it's doing (the NSA)".

8 As suggested by the German Information Security Agency, GISA, or BSI (Frank W. Felzmann and Manfred Kramer) already some years ago.
} 
This is something you should ask your Minister of Finance for an opinion or at least for an educated guess.

In criminal bankruptcies it would be much more difficult than today, if not impossible, to antedate all necessary transactions and save property from the hands of the creditors.

Ask any lawyer, for an opinion or at least for an educated guess. You don't possibly have to travel to or call for VADUZ/Liechtenstein, where every lawyer is said to be "the right lawyer".

Think then about electronic "verificates" (not in my Webster, have I innovated a new English word?, or is the correct term receipt or voucher? - "written record or receipt that serves as proof of a transaction") with digests, you only need to check a string of $32 \mathrm{HEX}$, and not the whole file or folder or database with auditing programs.

- A written record or receipt that does not serve as proof of a transaction is logically not a verificate / receipt / voucher, as described in the various Bookkeeping Act's of the various jurisdictions.

The Digital Signature Standard would allow authors to encrypt their documents with a key known only to them.- OK. - Assuming the author has not disclosed his password to others, this identifying key could serve as a sort of electronic evidence seal. - Yes, sure, but if the bookkeeping is sealed with encryption, it gives an easy excuse and escape back-door for dishonest businessmen:

- "I am not so familiar with information security software and suddenly I somehow lost the passwords and the secret keys. This is sad, but it certainly is no crime. Sorry, cops, no case, just human error."

Presenting evidence in the court with One-Way Hash Function would be easy. The Honorable Judge can convince himself (and the jurors, too) when he gets the file from the prosecutor as an exhibit \#1 and the hex string from the mouth of the witness (like B1 4E 2A BD 9608 8B A4 6783 D1 09 FE 52 56 6C).

Then His Excellency calculates with his own laptop a comparison, which takes about a microsecond, and, VOIL A, if there is a match, it is beyond reasonable doubt (kein vernünftiger $Z$ weifel, conviction raisonnée).

- The defending attorney, who is left his/her mouth wide open, cannot successfully deny the comparison result.

- There is only one minor problem left. Most lawyers are still computer illiterate.

We started this paper by citing Dr. Hans Gross. It can as well be ended by repeating his wise words: 
"Everything is lost forever in finding the truth in criminal proceedings, if the Honorable Judge can not understand the basics of what the various experts are saying and all is new and strange to him."

N.B. References (41, 70 in the "original") are listed in same order as they appear in the text, because it seems to make more sense than the usual alphabetical order. The figures $(5,40$ in the "original") are listed after the references.

\section{REFERENCES}

1. The Council of Europe Recommendation No. R (95) 13, Appendix, IV. Electronic evidence, Strasbourg 1995. Council of Europe Recommendation No. R (95) 13, of the Committee of Ministers to Member States Concerning of Problems of Criminal Procedural Law Connected with Information Technology; now available from the Council of Europe Publishing, F-67075 Strasbourg Cedex, 80 pages, ISBN 92-871-2971-1.

2. Chairman Leon Strous' TC 11.5 Zürich Working Conference Annotation, June 1997.

3. The Council of Europe Terms of Reference of the Committee of Experts on Crime In Cyberspace, Strasbourg, April 1997.

4. ISO/IEC Hash-Functions (10118-1-4) and Digital Signature Standards (14888-1-3), Geneva, 1993-1997.

5. David Kahn, The Codebreakers, New York, 1996.

6. Black's Law Dictionary, De Luxe Edition, St. Paul, MN, 1992.

7. Hans Gross, Handbuch für Untersuchungsrichter, Wien, 1893.

8. Jürgen Thorwalds, Das Jahrhundert der Detektive, Weg und Abenteuer der Kriminalistik pp. 134-178 in the Finnish version), Zürich 1965.

9. Howard Coleman and Eric Swenson, DNA in the Courtroom, Seattle, 1995.

10. Claude E. Shannon and Warren Weaver, The Mathematical Theory of Communication (New York, 1949, reprinted 1975).

11. Aristotle, The Art of Rhetoric, Penguin Books, 1989, and Metaphysics (the Finnish version), Helsinki, 1990.

12. GAIUS IULIUS CAESAR, COMMENTARII DE BELLO GALLICO, Helsinki, 1927 (2nd ed.).

13. Matti Tenhunen, The Finnish Answer to professor Ulrich Sieber for his Comparative Research Study of Dissemination of Illegal Contents in International Computer Networks, June 1997.

14. Protocol of the PC-CY first meeting at the Council of Europe Headquarters, Strasbourg, 14 - 16 April 1997.

15. Kolmogorov, Foundations of the Theory of Probability, in English 1950, the original "Grundbegriffe der Wahrscheinlichkeitsrechnung" was published in 1933, but, to be scientifically accurate, my Helsinki University copies are printed in New York, 1946 and 1950, donated to Finland by the 81st US Congress. 
16. Walter R. Fuchs. Mathematics (in Finnish), München, 1966.

17. John Watkinson, The Art of Data Recording, Oxford, 1994.

18. Warner New Media CD-ROM How Computers Work, The complex world of computers made simple, TIME-LIFE, $1994 .^{9}$

19. Kvanttipiste, The Quantum Dot, A Journey into the Future of Microelectronics (in Finnish), Helsinki 1995.

20. Adel S. Sedra and Kenneth C. Smith, Microelectronic Circuits, Toronto, 1991 (3rd ed.).

21. Wolfgang Kässer, Wahrheitserforschung im Straprozess, Berlin, 1974.

22. Rudolf Carnap, Der Logische Aufbau der Welt, Hamburg 1966.

23. SOU 1992:110, Computer Crime Report ("Databrottsutedning"), Stockholm, 1992.

24.SOU 1996:40, Handling of Electronic Documents ("Elektronisk dokumenthantering"), Stockholm, 1996.

25. Stuart S. Kind, Science Against Crime, London, 1972.

26. Dave Williams, L'attentat contre le World Trade Center de New York, Revue Internationale de Police Criminelle, Numero 452-453, 1995, pp 32-36.

27. Bruce Schneier, Applied Cryptography, Protocols, Algorithms and Source Code in C, New York, 1996.

28. Alfred J. Menezes, et alii, Handbook of Applied Cryptography, Boca Raton, Fla, 1997.

29. Matti Tenhunen, The Finnish Answer to the OECD Questionnaire Review of the 1992 Guidelines for the Security of Information Systems, November 1996.

30. Gesetz zur digitalen Signatur, Signaturgesetz, SigG, Referentenentwurf, Stand 19. September 1996, Bonn, 1996 (a new one available in the Web).

31. The 1734 Year's Law (for Sweden and Finland, the historical masterpiece among all Law Codifications), Finnish version, printed in Helsinki 1866.

32. Tauno Tirkkonen, The Finnish Criminal Procedural Law, Part II, Finnish version, Porvoo, 1962

33. Mark M. Pollitt, Computer Forensics: An Approach to Evidence in Cyberspace, RCMP IT Security Bulletin, pp. 5-7, April 1996.

34. Werner Paul, EDV-Ausbildung der Ermittlungsbeamten und im Aufbau einer neuen kriminaltechnischen Dienststelle mit dem neuen Berufsbild des polizeilichen EDV-Sachverständigen, Proceedings of the EICAR'92 Munich Conference.

35. Proceedings of the Computer Evidence Conferences, Quantico 1993, Baltimore 1995, Melbourne 1996, and The Hague 1997.

36. Ulrich Seidel, Bestandsaufnahme über elektronischen Signaturverfahren, St. Augustin, September 1992.

\footnotetext{
${ }^{9}$ Currently I am trying to get the permission from Time-Life, Warner New Media, California, to translate this into Finnish. Most of the cases investigated by the police are lost in the courts, because the vast majority of the prosecutors and judges have not the faintest idea of what is "Under the Hood" in IT. The legal consequences of the understanding of the real material nature of data and information are the beginning of the whole wisdom of finding the truth in criminal proceedings of IT-related crime.
} 
37. The Finnish Bookeeping Act, 1973.

38. Department of Justice (Scott Charney and Martha Stansell-Gamm), Federal Guidelines: Searching and Seizing Computers, Washington DC, July 1994.

39. Davies, D.W., Price, W.L., Security for Computer Networks, An Introduction to Data Security in Teleprocessing and Electronic Funds Transfer, New York 1984.

40. Joerg Rosemann, Die elektronische Unterschrift, Einsatz digitaler Signaturverfahren im Rahmen der EDV-Beweismittelsicherung, Kriminalistik 8-9/94, s. 575-578.

41. Schneier, Bruce, Applied cryptography: protocols, algorithms, and source code in $C, 1$ st ed. 1994, 2nd 1996.

\section{FIGURES:}

Figure 1. The Production Rule of Probability, Cover page of Mathematics (Matematiikka in Finnish) by Walter R. Fuchs, Munich 1966.

Figure 2. John Watkinson, The Art of Data Recording, Oxford 1994, page 9 (here as Figure 2, in the original as figure 1.6, Basic Physics Behind All Data Recording).

Figure 3. Digital Electronic Writing in ROM, RAM, Warner New Media CDROM How Computers Work, The complex world of computers made simple, TIME-LIFE, 1994. Bits of Data to show the electronic writing in RAM and ROM.

Figure 4. Electrone. Metal Oxide Semiconductor Field Effect Transistor (MOSFET), Kvanttipiste, ( 1995 Spektrum Akademischer Verlag GmbH, original English version THE QUANTUM DOT, A Journey into the Future of Microelectronics, page 72, Picture 4.4. Switching a positive charge to the director electrode of a MOSFET allows the current to go through the device.

Figure 5. The Compare Icon, 3rd ISO/IEC CD 14888-1, April 11th, 1997, page 6, Legend for the figures: Compare. 